$\begin{array}{r}\text { Phinisi Integration Review } \\ \text { Vol. 2, No.1, Februari 2019 Hal 165-173 } \\ \text { Website: } \underline{\text { http://ojs.unm.ac.id/pir }} \\ \text { p-ISSN: } 2614-2325 \text { dan e-ISSN: 2614-2317 } \\ \hline\end{array}$

\title{
Aktivitas Ekonomi Masyarakat Bugis di pasar Terong Kota Makassar
}

\author{
Shahnaz Wulandari ${ }^{(1)}$ \\ Jurusan Ilmu Pengetahuan Sosial, Program Pascasarjana Universitas Negeri Makassar \\ email: shanaz_wulandari@yahoo.com
}

\begin{abstract}
Abstrak. Penelitian ini bertujuan untuk mengetahui (1) aktivitas ekonomi antar pedagang Suku Bugis di Pasar Terong, (2) pola persaingan antar pedagang Suku Bugis di Pasar Terong Kota Makassar (3) Faktor pendorong masyarakat Suku Bugis melakukan aktivitas ekonomi di Pasar Terong Kota Makassar. Jenis penelitian yang digunakan adalah penelitian kualitatif. Penelitian kualitatif menekanka pada kejadian atau fenomena dan gejala yang diungkap maknanya. Penelitian kualitatif dapat didesain untuk memberikan sumbangan teoritis, praktis, kebijakan, masalah dan tindakan. Adapun teknik pengambilan sasaran penelitian yang disebut informan adalah secara purposive sampling yaitu melalui pertimbangan tertentu . Dalam pengumpulan data, peneliti bertindak sebagai instrumen penelitian. Data yang diperoleh melalui dua sumber yaitu informan dan dokumen. Teknik pengumpulan data dilakukan melalui observasi, , dokumentasi dan wawancara dengan melibatkan 8 orang informan. Pengabsahan data di lakukan dengan Membercheck adalah proses pengecekan data yang diperoleh peneliti kepada pemberi data. Dan Trianggulasi merupakan tekhnik pemeriksaan kebenaran data sebagai pembanding atas data yang diperoleh Hasil penelitian mengungkapkan bahwa: (1) dari aktivitas ekonomi masyarakat Bugis yang terjalin tumbuh rasa kepercayaan sesama pedagang semakin kuat dikarenakan berasal dengan suku yang sama, serta mereka menjalin hubungan diluar pasar dengan cara arisan (2) dalam persaingan sesama masyarakat suku Bugis mereka mengikat dengan sistem langganan untuk pembeli dengan cara melayani dengan baik, memberikan pinjaman dan pemberian hadiah (3) Faktor mempengaruhi aktivitas ekonomi masyarakat Suku Bugis dengan adanya ajakan dari hubungan keluarga dan rasa saling percaya dalam memperluas hubungan kerja sama. Dalam pengaruh persaingan perdagangan yang ada, mampu melihat adanya perputaran ekonomi yang bagus antara penjual dan pembeli sesama masyarakat Bugis dipasar Terong Kota Makassar
\end{abstract}

Kata Kunci: Aktivitas Ekonomi; Pasar; Masyarakat Suku Bugis

Abstract. This study aims to determine (1) economic activity among Bugis tribe traders
in Terong Market, (2) patterns of competition between Bugis tribe traders in the Eggplant
Market of Makassar City (3) The driving factor for Bugis tribe people doing economic
activities in Makassar Eggplant Market. The type of research used is qualitative research.
Qualitative research focuses on events or phenomena and symptoms that are revealed in
their meaning. Qualitative research can be designed to make theoretical, practical
contributions, policies, problems and actions. The research target technique called
informants is by purposive sampling, namely through certain considerations. In collecting
data, researchers act as research instruments. Data obtained through two sources, namely
informants and documents. The technique of collecting data was done through
observation, documentation and interviews involving 8 informants. Data validation done
with Membercheck is the process of checking data obtained by researchers to the data
giver. And Trianggulasi is a technique for checking the correctness of data as a 
comparison of the data obtained The results of the study revealed that: (1) the economic activities of the Bugis community that had grown grew a sense of trust among fellow traders stronger because they came from the same tribe, and they established relationships outside the market by arisan (2) in competition with fellow Bugis tribesmen subscription system for buyers by serving well, providing loans and giving gifts (3) Factors influencing economic activities of the Bugis Tribe with the invitation of family relations and mutual trust in expanding cooperative relationships. In the influence of existing trade competition, being able to see a good economic turnover between sellers and buyers of fellow Bugis people in the market of the eggplant city of Makassar

Keywords: Economic Activity; Market; Bugis Tribe Community

Ini adalah artikel dengan akses terbuka dibawah licenci CC BY-NC-4.0

(https://creativecommons.org/licenses/by-nc/4.0/).

\section{PENDAHULUAN}

Kota Makassar merupakan Ibukota dari Provinsi Sulawesi Selatan. Kota ini semakin lama semakin mengembangkan dirinya kearah metropolitan yang kental dengan teknologi, modernisasi serta hiruk pikuk aktivitas masyarakat yang aktif mengejar aspek ekonomis dikesehariannya. Kota makassar terdiri dari 14 kecamatan dan 143 kelurahan serta menjadi salah satu kota yang terpandang dimata nasional. Seperti yang terbahas di atas bagaimana kaum urban khususnya masyarakat Suku Bugis menjadikan Kota Makassar ini sebagai tempat untuk mencari dan mendapatkan penghidupan. Ada banyak sekali jumlah keluarga yang kini berdomisili di Kota Makassar ini, mereka berada dan menyesuaikan diri didalam masyarakat yang multikultural. Bukan berarti mereka yang hanya kaum urban tidak dapat bersaing dalam segala aspek di Kota Makassar ini, banyak dari mereka dapat bersaing dalam ranah ekonomi walaupun dilihat kebanyakan Suku Bugis yang berstatus para masyarakat pendatang dan melingkupi masyarakat etnik tersebut. Dengan demikian sudah diketahui bahwasanya keempat etnik besar di Sulawesi Selatan yang terdiri dari Mandar, Toraja, Bugis, dan Makassar berpeluang untuk mengandalkan setiap kekhasan suku masing masing.

Kota Makassar merupakan Ibukota dari Provinsi Sulawesi Selatan. Kota ini semakin lama semakin mengembangkan dirinya kearah metropolitan yang kental dengan teknologi, modernisasi serta hiruk pikuk aktivitas masyarakat yang aktif mengejar aspek ekonomis dikesehariannya. Kota makassar terdiri dari 14 kecamatan dan 143 kelurahan serta menjadi salah satu kota yang terpandang dimata nasional. Seperti yang terbahas di atas bagaimana kaum urban khususnya masyarakat Suku Bugis menjadikan Kota Makassar ini sebagai tempat untuk mencari dan mendapatkan penghidupan. Ada banyak sekali jumlah keluarga yang kini berdomisili di Kota Makassar ini, merekaberada dan menyesuaikan diri didalam masyarakat yang multikultural. Bukan berarti mereka yang hanya kaum urban tidak dapat bersaing dalam segala aspek di Kota Makassar ini, banyak dari mereka dapat bersaing dalam ranah ekonomi walaupun dilihat kebanyakan Suku Bugis adalah para masyarakat pendatang .

Sebagian besar pekerja informal masyarakat bugis khususnya di perkotaan terserap ke dalam sektor perdagangan salah satunya adalah mereka yang berprofesi sebagai pedagang yang telah menjadi sebuah alternatif pekerjaan yang cukup populer, Hal ini terkait dengan cirinya mudah dengan modal yang dIbutuhkan relatif kecil dan tidak memerlukan prosedur yang berbelit belit. Bahkan aktivitas ekonomi informal semacam ini dianggap sebagai kantong penyelamat selama masa krisis ekonomi pada tahun 1997/1998 ( Indarwati, 2009)

Perdagangan di Pasar Terong seperti dapat dilihat pelaku ekonomi dan aktivitas di Pasar Terong Makassar 1/2 dari pedagangnya adalah masyarakat Suku Bugis yang dimana mereka saling percaya dikarenakan memiliki ikatan etnik sesama penjual. Dengan cara begitu mereka tidak terputus akan silaturahmi dan cara mempertahankan perekonomian mereka di Pasar Terong. Pasar Terong adalah pasar tradisional 
yang berada tepatnya di Jalan Terong, Kelurahan Wajo Baru, Kecamatan Bontoala. Pasar Terong sebagai tempat berlangsungnya interaksi antara individu individu dan kelompok menjadikan terjadinya proses pertukaran. Pertukaran merupakan konsep yang berhubungan dengan sosok - sosok tentang pengubahan barang atau jasa tertentu dari individu-individu atau kelompok kelompok lain guna mendapatkan barang atau jasa yang dIbutuhkan (Sairin, 2002: 41). Perilaku-perilaku para pelaku transaksi dapat diamati di dalam pasar (Koentjaningrat 1996: 74-75).

Dilihat dari lokasi ini Pasar Terong ini terkenal sebagai pemasok sembilan bahan pokok. Selain itu pasar terong dikenal dengan sayur-sayurannya yang lebih murah dibanding pasar-pasar lain yang ada di pusat kota makassar. Sehingga pasar ini terkenal dengan sebutan pasar induk untuk para pedagang kecil yang meramaikan pasar terong di pagi hari hingga sore hari. Pedagang dan pembelinyapun berasal dari daerah yang beragam. Pasar inipun setidaknya menyuplai ke daerah-daerah lain hingga 18 provinsi khususnya Sulawesi dan Indonesia Timur.

Penelitian ini dilakukan untuk mengetahui tentang kuatnya hubungan se etnik masyarakat Suku Bugis sebagai kelompok perantau yang melakukan kegiatan ekonomi di pasar terong daerah Makassar. Selain itu untuk mengetahui bagaimana kegiatan ekonomi terjalin, disisi lain juga dilihat bagaimana persaingan para pedangang sesama Suku Bugis untuk mengait pelanggan serta mempertahankan strategi penjualan, yang diketahui bukan hanya satu suku saja yang ada di pasar terong dalam usaha sektor informal ini.

Berdasarkan hasil dari pengamatan pra survey adanya juga campur tangan dari hubungan kekerabatan sesama penjual di Pasar Terong yang berjalan dengan baik sehingga para pedagang mampu bersaing sehat dengan sesamanya. Bahkan mereka saling membantu dalam hal persaingan mananggapi pembeli walaupun tempat untuk berjualan tersebut sama. Dikarenakan adanya pandangan masyarakat bugis bahwa implementasi makna hidup ini tampak dalam berbagai usaha dengan menjadikan rekan seetnik sebagai partner usaha. Makan dilihat tidak heran jika asal usul, adat istiadat, dialeg (budaya) dan simbol suku lainnya kerap dijadikan pertimbangan yang utama dalam melakukan kerjasama (Kesuma,
2012: XI ). Dengan memperluas hubungan serta aktivitas ekonomi sesama para Suku Bugis maka akan ada suatu kerjasama atau tindakan dalam pencapaian suatu keuntungan bersama. Ada hubungan timbal balik dalam memperoleh keuntungan dan keuntungan yang dimaksudkan disini dapat dalam bentuk pencapaian tujuan masing-masing pihak yang bekerjasama. Dengan adanya jaringan kerjasama maka eksistensi bisnis sebagai pedagang tetap terjaga, dan dapat dengan mudah mengembangkan usaha yang dimiliki. Dengan begitu maka dapat meningkatkan pula taraf hidup sosial ekonomi para perantau tersebut

Pada mulanya istilah pasar dikaitkan dengan pengertian tempat pembeli dan penjual bersama-sama melakukan pertukaran. Pengertian itu berkembang menjadi pertemuan atau hubungan antara permintaan dan penawaran (Assauri, 2010: 98).

Hal ini merupakan pengertian pasar secara konkrit, artinya pengertian pasar dalam kehidupan sehari-hari, yaitu tempat orang-orang bertemu untuk melakukan suatu transaksi jual beli barang. Seiring berkembangnya zaman dan teknologi, pasar tidak hanya terbatas pada pertemuan antara penjual dan pembeli, tetapi memiliki arti yang lebih luas. Pengertian yang lebih luas dikemukakan oleh Geerts bahwa pasar sebagai suatu pranata ekonomi dan sekaligus cara hidup, suatu gaya umum dari kegiatan ekonomi yang mencapai segala aspek (Azis, 2006:4)

Dasar penetapan suatu tempat jual beli umum sebagai pasar harus mencakup unsur sebagai berikut:

1. Unsur pertemuan penjual pembeli, baik dari golongan masyarakat ekonomi lemah maupun masyarakat menengah dan atas.

2. Unsur penyediaan barang-barang keperluan sehari-hari.

3. Unsur pasar sebagai tempat kegunaan umum (Murtolo, dkk.1996:22).

Dalam intervensi pasar menurut Alexander (1999) dalam Ahmad (2005) menggunakan tiga konsep, yaitu dagang, pedagang, dan perdagangan. Konsep dagang menempatkan pasar sebagai arena sistem tukar menukar barang dan sirkulasi barang dagangan. Konsep pedagang menggambarkan tipe pedagang dan lembaga-lembaga sosial yang menyalurkan mereka ke hubungan sosial yang rumit. Sedangkan perdagangan diartikan sebagai 
suatu aliran informasi yang terstruktur berdasarkan budaya.

Sosial ekonomi adalah kedudukan atau posisi seseorang dalam kelompok masyarakat yang ditentukan oleh jenis aktivitas ekonomi, pendidikan serta pendapatan. Dalam pembahasannya sosial dan ekonomi sering menjadi objek pembahasan yang berbeda. Dalam konsep sosiologi manusia sering disebut dengan makhluk sosial yang artinya manusia tidak dapat hidup wajar tanpa adanya bantuan dari orang lain, sehingga arti sosial sering diartikan sebagai hal yang berkanaan dengan masyarakat. Dilihat sejak masa kolonialisme, pendidikan dianggap sebagai faktor penting untuk meningkatkan kesejahteraan bangsa (Wirutomo,2012: 94) .

Masyarakat Indonesia yang biasa dikenal dengan penduduk prIbumi pada masa kolonial mendapat kesempatan untuk menyekolahkan anak-anaknya, meskipun masih banyak keterbatasan karena adanya pembedaan perlakuan dalam masyarakat, adanya perbedaan jenjang pendidikan pada masa kolonial pada umumnya membuat peluang masyarakat untuk memperoleh pekerjaan lebih sedikit sehingga berdampak pada pandapatan yang mempengaruhi kesejahteraan.

Manusia merupakan mahluk satu-satunya di muka bumi ini yang mampu berbudaya, yang membedakan dengan binatang yang tidak mampu dan tidak akan pernah mengadakan penukaran barang. Manusia mampu menukarkan barang dengan orang lain dalam memenuhi kebutuhannya, hal ini mengungkapkan kegiatan ekonomi selalu dikaitkan dengan kegiatan produksi dan tukar-menukar. Dua kegiatan ini adalah titik perhatian perilaku ekonomi manusia (Sukmana 2005: 69)

Bugis merupakan kelompok etnik dengan wilayah asal Sulawesi Selatan. Penciri utama kelompok etnik ini adalah bahasa dan adat-istiadat, sehingga pendatang Melayu dan Minangkabau yang merantau ke Sulawesi sejak abad ke-15 sebagai tenaga administrasi dan pedagang di Kerajaan Gowa dan telah terakulturasi, juga dikategorikan sebagai orang Bugis. Saat kehidupan diatur dengan pangngaderreng (undang-undang sosial) sebagai falsafah tertinggi yang mengatur masyarakat sampai penaklukan seluruh tanah Bugis tahun 1906, maka unsur yang awalnya hanya terdiri atas empat kemudian berubah menjadi lima. Ini untuk mengakomodasi diterimanya Islam sebagai pegangan hidup. Sistem yang salingmengukuhkan pangngaderreng didirikan atas 1) wariq (protokoler kerajaan), 2) adeq (adat-istiadat), 3) bicara (sistem hukum),4) rapang (pengambilan keputusan berdasarkan perbandingan), dan 5) saraq (syariat Islam) ( Rahman : $2006: 387$ )

\section{METODE PENELITIAN}

Jenis penelitian yang digunakan adalah penelitian kualitatif. Penelitian kualitatif menekanka pada kejadian atau fenomena dan gejala yang diungkap maknanya. Penelitian kualitatif dapat didesain untuk memberikan sumbangan teoritis, praktis, kebijakan, masalah dan tindakan. Adapun teknik pengambilan sasaran penelitian yang disebut informan adalah secara purposive sampling yaitu melalui pertimbangan tertentu . Dalam pengumpulan data, peneliti bertindak sebagai instrumen penelitian. Data yang diperoleh melalui dua sumber yaitu informan dan dokumen. Teknik pengumpulan data dilakukan melalui observasi, , dokumentasi dan wawancara dengan melibatkan 8 orang informan. Pengabsahan data di lakukan dengan Membercheck adalah proses pengecekan data yang diperoleh peneliti kepada pemberi data. Dan Trianggulasi merupakan tekhnik pemeriksaan kebenaran data sebagai pembanding atas data yang diperoleh

\section{HASIL DAN PEMBAHASAN}

\section{Aktivitas Ekonomi Masyarakat Bugis di Pasar Terong Kota Makassar}

Berdasarkan hasil penelitian yang dilakukan oleh peneliti bahwa semua dari informan yang diwawancarai, memiliki alasan tersendiri dalam melakukan aktivitas ekonomi adalah dimana mereka untuk memenuhi kebutuhan ekonomi sehari hari mereka yang berada di Kota Makassar ini. Sebagai kelompok perantau yang cukup besar di Kota Makassar untuk mendapatkan suatu tempat dalam ranah pekerjaan informal cukuplah susah. Yang diketahui bahwa untuk bergabung atau bekerja harus memiliki skill atau kepintaran bergaul untuk bisa diterima diranah perdagangan ini. Kebanyakan dalam kelompok parantau ini mengikuti jejak dari orang tua, saudara, keluarga maupun teman agar bisa memiliki tempat dimata perdagangan yang memiliki persaingan ketat dalam berwirausaha 


\section{A. Tumbuh Rasa Kepercayaan}

Seorang pedagang memiiliki etika antar pedagang yang berada dilokasi yang sama untuk melakukan kegiatan berdagang. Seseorang yang terlibat dalam kegiatan perdagangan atau jual beli harus memperhatikan tata cara maupun aturan main yang mengatur bagaimana seharusnya seorang berusaha di bidang perdagangan agar mendapatkan berkah. Dalam transaksi jual beli, pedagang dan pembeli harus saling jujur, artinya tidak berbohong, tidak menipu, tidak mengada-ngada fakta, tidak bekhianat, serta tidak pernah ingkar janji dan lain sebagainya. karenakan, transaksi jual beli yang tidak didasarkan atas perbuatan tidak jujur selain merupakan perbuatan yang jelas-jelas akan menimbulkan dosa, juga akan menimbulkan pengaruh negatif kepada kehidupan pribadi dan keluarga pedagang itu sendiri dan begitu pula yang harus dilakukan antar sesama pedagang.

Kepercayaan merupakan modal sosial dimana seseorang akan mampu membuat akses lebih jauh dalam usaha. Permodalan, perbankan, akses sosial, kelancaran komunikasi dan interaksi sesama anggota dalam jaringan sosial, merupakan hasil dari kepercayaan ini. Oleh karena itu membangun kepercayaan ini membutuhkan konsistensi usaha, ketepatan janji, dan pemahaman akan hak dan kewajiban sebagai bagian dari paguyuban ini.

\section{B. Mempererat Hubungan Silaturahmi Dengan Arisan \\ Selain melakukan kegiatan jual menjual} di Pasar Terong Kota Makassar para pedagang sesama suku bugis juga melakukan kegiatan di Pasar yaitu melakukan kegiatan yang mempererat hubungan mereka dengan cara arisan. Arisan adalah sutau kegiatan pengumpulan uang dengan sederhana dengan cara diundi dilaksanakan setiap bulan atau perminggu. Para pedagang ini menyempatka wakti setiap selesai berjualan berkumpul yang tempat sudah disepakati.

Arisan ini terbentuk sesama kelom masyarakat suku bugis maupun bukan masyarakat bugis. Alasan untuk membentuk arisan mereka mampu mempererat hubungan mereka sesama pedagang dan memanfaatkan waktu pertemuan mereka untuk saling mengenal dan membahas soal perdagangan mereka. Bagi orang yang sIbuk bekerja, ia mungkin jarang bersosialisasi dengan orang lain dengan pedagang lainnya. Saat di tempat penjualan, yang ada hanya relasi penual dan pembeli dengan Ikut arisan membantu seseorang bersosialisasi dengan sesama pedagang

\section{Persaingan Para Pedagang Suku Bugis}

Peneliti ini akan menjelaskan bagaiamana para pedagang yang ada di Pasar Terong Kota Makassar bersaing dengan sehat dengan para pedagang lainnya, oleh karena itu peneliti akan menjawab dan menjelaskan persaingan pedagang masyarakat bugis dari beberapa informan yang sangat beragam tentang persaingan tersebut. Barang dan jasa yang dijual di pasar ini bersifat homogen dan tidak dapat dibedakan. Semua produk terlihat identik. Pembeli tidak dapat membedakan (perfect competition) adalah sebuah jenis pasar ekonomi dan informan dengan jumlah penjual dan pembeli yang sangat banyak dan produk yang dijual bersifat sama. Harga terbentuk melalui mekanisme pasar dan hasil interaksi antara penawaran dan permintaan sehingga penjual dan pembeli di pasar ini tidak dapat memengaruhi harga dan hanya berperan sebagai suatu barang berasal dari produsen yang satu dengan yang lainnya. Tidak dapat diungkiri bahwa strategi tersebut mampu mempertahankan pembeli mereka dengan cara yang sederhana. Persaingan ini membuat para pedagang masyarakat suku bugis mampu untuk tetap menjaga eksistensinya dimata pembeli agar pembeli tersebut tidak beripindah ke lain tempat.

\section{a. Memberikan Pinjaman}

Dari hasil penelitian yang dilakukan oleh peneliti dalam wawancaranya bagaimana para pedagang ini bersainng dengan penjual lainnya yaitu dengan memberikan pinjaman sesuai dengan syarat yang ditetapkan oleh penjual tersebut. Syarat yang ditentukan ialah pembeli yang telah berbelanja yang sudah lama dan menjadi pelanggan penjual tersebut. Maka dari itu penjual memberikan pinjaman yang cukup menguntungkan bagi sipembeli

Pinjaman yang diberikan dalam proses pembelian dengan cara mengambil barang yang banyak dan sebagian bisa dipinjam dan sebagiannya lagi dibayar sesuai kesepakatan. 
Metode pinjaman ini cukup direspon baik oleh si pembeli yang dimana mereka meminjam barang dagangan yang mereka beli dan membayar tanpa waktu yang singkat sehingga kapan saja pembeli ini untuk membayar. Dengan cara ini pembeli enggan untuk pindah ke tempat lain dan menetap di penjual tersebut. Keuntungan selanjutnya ialah meningkatkan hubungan dengan konsumen. Penjualan secara pinjjam ini menuntut adanya saling keterbukaan informasi antara penjual dan pembeli. Konsumen yang ingin mendapatkan pelayanan ini harus memberikan informasi yang sebenarnya mengenai keadaan konsumen baik itu dari segi keuangan maupun latar belakang konsumen itu sendiri. Dengan adanya sikap saling terbuka ini, penjual akan lebih memahami kondisi konsumen dan timbul kepercayaan satu sama lain sehingga transaksi yang akan dilaksanakan nanti akan berjalan dengan lancar.

Pedagang yang berani memberikan pinjaman kepada pembeli melihat latar belakang dari pembeli tersebut apakah pembeli ini bagus dalam pembelanjaan atau tidak. Dan salah satu kebanyakan yang dilihat juga dari asal mereka dimana. Lokasi Pasar Terong sebagai pasar induk yang para penjual dan pembelinya bersar dari beberapa daerah maka dari itu melihat asalusul pelanggan ini wajib di perhatikan untuk melakukan transaksi yang aman dalam jangka waktu yang panjang.

\section{b. Melayani dengan Sepenuh Hati}

Pelanggan adalah raja. Melayani seorang pelanggan atau pembeli secara baik adalah suatu keharusan agar pelanggan merasa puas dan menjadi pelanggan setia. Pelanggan merasa puas atas pelayanan anda sedikit banyak akan membuat virus pemasaran terbaik tanpa perintah. Para pelanggan dengan suka rela menceritakan hal-hal yang terbaik atas pelayanan dalam bisnis anda. Dengan beberapa tambahan pelanggan, otomatis akan meningkatkan penghasilan. Bisnis tidak akan kehilangan pelanggan, tapi akan bertambah banyak. Keterampilan dasar pelayanan terhadap pelanggan dapat diterapkan dalam beberapa strategi pelayanan dalam rangka membangun dan meningkatkan citra positif pada bisnis.

\section{c. Memberikan Hadiah Setiap Hari Raya dan Akhir Tahun \\ Memiliki banyak pelanggan yang loyal} menjadi impian bagi hampir semua para pedagang masyarakat bugis yang ada di Pasar Terong Kota Makassar. Bukan hanya membeli dan berlangganan, tapi mereka yang juga mau dengan senang hati merekomendasikan bisnis kita kepada orang lain. Memiliki pelanggan yang seperti ini tentu tidaklah mudah. Mereka bukan hanya senang dengan jualan, bukan juga puas dengan pelayanan yang kita berikan, namun juga dengan kepedulian kita terhadap hall kecil yang bahkan mereka pun lupa akan itu. Dengan memberikan hadiah pada pelanggan yang setia akan membuat pelanggan tersebut merasa senang dan dihargai sehingga akan kembali pada penjual tersebut untuk membeli dagangan tersebut. Perlu juga diketahui bahwa mengenal setiap pelanggan setia agar pelanggan semakin senang berada diwilayah penjualan mereka.

dalam hasil penelitian yang diteliti bahwa mereka memberikan hadiah pada pelanggan yang sudah lama menjadi pembeli mereka dengan cara memberikan benda seperti pada saat hari raya. Mereka memberikan seperti sarung, mukenah, gelas dan lain lain. dan ada juga penjual yang memberikan pada saat akhir tahun seperti emas, baju, dana alat dapur tergantung bagaiamana penjual tersebut dekat dengan pembeli tersebut.

Setiap pembeli pasti pembelajaan mereka berbeda dengan pembeli lainnya. Ada yang banyak dan ada yang sedikit. Maka dari itu penjual mengukur sebagaiamana loyal pembeli tersebut ditempatnya dan seberapa banyak barang dagangan yang ia beli ditempatnya. Pemberian ini adalah salah satu bagaiamana cara menarik perhatian oleh si konsumen untuk tetap berbelanja dengannya dan tidak berpindah tempat. Walaupun dalam ranah Pasar Terong ini masih ada beberapa pedagang yang kehilangan pembeli walaupun sudah melakukan hal ini. Tidak dapat dipungkiri bahwa setiap pembeli mempunyai selera masing-masing untuk berpindah tempat walaupun dalam suatu lokasi

\section{Faktor Pendorong Masyarakat Bugis Melakukan Aktivitas Ekonomi di Pasar Terong}

sebagai kelompok perantau sangat sulit mendapatkan pekerjaan apabila tidak memiliki keahlian tersendiri. Di Kota Makassar adalah kota yang dimana tempat pelarian para masyarakat perantau untuk tetap bekerja dan berkembang. Maka dari itu tidak dapat 
dipungkiri wilayah tersebut sudah menjadi padat penduduk bagi kelompok perantau baik dalam Sulawesi Selatan maupun diluar Sulawesi dalam segi pekerjaan,politik,maupun pendidikan.

Perpindahan masyarakat dari desa menuju kota merupakan salah satu penyebab terjadinya urbanisasi. Perpindahan tersebut terbagi menjadi 2 kategori, yaitu migrasi dan mobilitas penduduk. Migrasi penduduk merupakan perpindahan penduduk desa menuju kota dengan tujuan menetap di kota. Sedangkan mobilitas penduduk merupakan perpindahan dengan tujuan tidak menetap atau hanya sementara

Dalam ranah masyarakat bugis ini sudah menjadi hal biasa dalam melakukan perantauan yang dalam bugisnya disebut denga passompe. Mereka kedaerah orang untuk memenuhi kebutuhan hidup dikampung bahkan ada yang menetap didaerah tersebut apabila mereka telah sukses didaerah orang. Salah satu contohnya adalah masyarakat suku bugis yang menetap di Makassar dan melakukan kegiatan ekonomi di Pasar Terong Kota Makassar. mereka sudah melakukan perdagang ini sampai turun temurun. Dari orang tua hingga anak-anak mereka dikarenakan mereka sudah menetap dan sukses dalam usaha berdagang .

\section{a. Ajakan keluarga}

Para masyarakat urban memiliki faktor pendorong untuk melakukan kegiatan ekonomi di Pasar Terong salah satunya ialah mengikuti ajakan keluarga. Sebagai kelompok perantau mengikuti ajakan dari keluarga adalah salah satu bantuan yang sangat di hargai sebagaimana mampu mengajarkan dan membimbing dalam soal perdagangan. Mereka mengikuti keluarganya yang dari awal memang ingin membantu dalam soal pekerjaan. Selain untuk membantu keluarga dikampung mereka juga ingin memenuhi kebutuhan mereka yang berada di pusat kota. Tanpa memiliki bantuan dari keluarga mereka mungkin takkan bisa mengikuti arus perdagangan yang ketat di Pasar Terong tersebut.

Dukungan sosial (sosial support) didefinisikan oleh Gottlieb dikutip Siregar (2010) sebagai informasi verbal maupun non- verbal, saran, bantuan yang nyata atau tingkah laku yang diberikan oleh orang-orang yang akrab dengan subjek di dalam lingkungan sosialnya atau yang berupa kehadiran dan halhal yang dapat memberikan keuntungan emosional atau berpengaruh pada tingkah laku penerimanya. Dapat dilihat bahwa dorongan sosial keluarga ini mampu mengubah hidup para masyarakat suku bugis untuk bekerja di perkotaan .

Mulai dari umur belia sampai umur dewasa para kelompok perantau ini mempelajari bagaimana berdagang dikota besar ini. Setelah lama mempelajari dari bantuan keluarga, mereka mampu membuka usaha sendiri dan memiliki toko sendiri sehingga bisa berkembang sampi sekarang. Motivasi keluarga adalah satu faktor masyarakat bugis melakukan kegiatan ekonomi yang begitu ketat dalam bersaing di zaman modern ini. Dorongan untuk bekerja dalam ranah ini adalah keuntungan bagi kelompok perantau ingin menetap di Kota Makassar.

\section{b. Adanya Hubungan Kerjasama}

Di dalam segi pekerjaan bisa terjadi persaingan antar pedagang (pedagang barang harian), disini para pedagang grosiran (pedagang barang harian) berlomba-lomba dan bersaing antar sesama mereka untuk mendapatkan keuntungan yang besar untuk menghidupi kehidupan ekonomi keluarganya masingmasing. Para masyarakat bugis yang bekerja di Pasar Terong Kota Makassar selain terjadi persaingan mereka juga melakukan hubungan kerja sama dengan konsumen maupun juga bekerjasama antar pedagang.

\section{c. Bagusnya Perputaran Ekonomi}

Wilayah Pasar Terong Kota Makassar adalah salah satu pasar yang diminati oleh pedagang kacil ( gerobak, kaki lima, grosiran) maupun pedagang besar. Pedagang tersebut melakukan traksaksi pembelian pada jam-jam yang tertentu untuk tidak mendapati pembelian yang padat. Pembelian padat terjadi di pagi hari yang dimana seluruh penjuru pembeli mendatangi Pasar Terong untuk memenuhi kebutuhan penjualnnya. Wilayah Pasar Terong adalah wilayah yang strategis dipusat kota dan sebagai pasar pematok harga dibandig pasar lain. Kegiatan tersebut dilakukan dalam menyepakati suatu proses pembelian yang sudah 
diatur oleh mereka. Perputaran ekonomi sangatlah mudah didapatkan dikarenakan proses transaksi yang dilakukan cukup mudah.

Pembeli yang berdatangan membuat perputaran ekonomi para pedagang yang ada di Pasar Terong Kota Makassar cukup terhitung banyak. salah satunya adalah para pedagang masyarakat suku bugis yang berjualan di tengah tengah Pasar Terong. Adanya kebutuhan yang wajib di beli untuk memenuhi kebutuhan penjualan memaksan para pembeli ini mendatangi Pasar Terong setiap hari untuk memenuhi kebutuhannya.

\section{SIMPULAN DAN SARAN}

\section{A. Kesimpulan}

1. Aktivitas masyarakat suku bugis yang mendiami Pasar Terong Kota Makassar adalah kegiatan untuk menyambung hidup didaerah perkotaan. Selain menjalani kegiatan penjualan para pedagang juga memiliki ikatan tersendiri sesama penjual. Ikatan yang terdiri dari rasa kepercayaan dikarekan selau bertemu setiap hari dan memiliki lokasi yang sama dan hubungan silaturahmi yang semakin kuat karena berasal dari daerah yang sama dan membentuk suatu perkumpulan arisan sesama pedagang .

2. Dengan Persaingan para pedagang adalah Bentuk hubungan sosial pedagang masyarakat bugis adalah dalam bentuk kerja sama, akomodasi dan persaingan serta pedagang menggunakan asas kepentingan sendiri. Namun tidak ada terjadinya pertentangan atau pertikaian (konflik). Tetapi setiap pedagang memiliki cara bersaing tersendiri yang dimana mamakai teknik untuk mengait pelangga dengan cara yaitu pemberian pinjaman, melayani dengan baik serta pemberian hadiah setiap tahun dan tahun baru

3. Faktor pendorong masyarakat bugis melakukan kegiatan di Pasar Terong Kota Makassar adalah salah satu usaha untuk memperbaiki hidup didaerah asal Dalam kegiatannya ada beberapa faktor yang (1) membuat masyarakat bugis bisa bersaing dengan pedagang lainnya diawali dengan ajakan keluarga. (2) ialah adanya hubungan kerjasama antar pedagang untuk melakukan suatu usaha sehingga usaha tersebut bisa berkembang. (3) ialah dalam lokasi Pasar Terong Kota Makassar berada pusat kota dan tempat para pedang kecil untuk membeli dan mereka jual kembali..

\section{B. Saran}

Sehubung dengan kesimpulan diatas, maka penulis ingin mengemukakan sara-saran sebagai berikut :

1. Para pedagang masyarakat bugis yang melakukan kegiatan di Pasar Terong Kota Makassar ini sebaiknya bagaiamana lebih meningkatkan hubungan yang terjalin antar semama pedagang baik sesama suku bugis maupun diluar suku bugis. Dalam pemberian kepercayaan hendaknya harus lebih memilah milah siapa saa yang akan diberikan kepercayaan agar diantara para pedagang tidak ada yang dirugikan.

2. Bagi para masyarakat suku bugis hubungan persaingan antar pedagang jangan sampai terbawa ke ranah konflik. Persaingan terjadi dalam suatu usaha adalah salah satu bagaimana cara mendewasakan para padagang agar lebih jujur dalam bersaing, yang dimana diketahui jualan bersifat homogen. Pedagang yang mengait para pembeli dengan beberapa cara adalah satu persaingan yang sehat maka dari itu sebaiknya para pedagang lebih berhati hati dalam memberikan pijaman kepada pelanggan yang belum diketahui latar belakangnya. Para pedagang harus lebih memperhatikan kualitas dari barang dagangan yang mereka jual agar daya saing mereka bisa dilihat oleh pembeli

3. Bagi Pemerintah, diharapkan untuk lebih memperhatikan wilayah penjualan dan menstabilisasikan ekonomi masyarakat agar semua golongan masyarakat sebagai produktor, distributor dan konsumen menjadi lebih aman, makmur dan sejahtera. 


\section{DAFTAR RUJUKAN}

Ammarel. 2003. Bugis Migration and Modes of Adapttaion to Local Situationsa (Athens: Ohio University,).

Assauri, Sofjan. 2010. Manajemen Pemasaran. PT Rajagrafindo Persada. Jakarta

Asis, Abdul. 2006. Peranan Pasar Banyorang Terhadap Masyarakat Pedesan Makassar: dapertemen kebudayaan dan pariwisata balai pelestarian sejarah dan nilai tradisional masyarakat

Kesuma, Andi Ima. 2012 Moral Ekonomi Manusia Bugis. Rayhan Intermedia :Makassar

Koenjaraningrat. 1996. Pengantar Antropologi. Jakarta. Universitas

Rahman 2006 Cinta, Laut dan Kekuasaan Dalam Epos La Galigo (Makassar: La Galigo Press,

Sukmana ,2005. Sosiologi Dan ekonomi

Sairin, Syafri, Pujo Semedi dan Bambang Hudayana . 2002. Pengantar Antropologi Ekonomi. Yogyakarta: Pustaka Pelajar.

Meinarno, E. A., Widianto, B., \& Halida, R. (2008). Manusia dalam Kebudayaan dan Masyarakat. Salemba Humani 